\title{
Acoustics of naturally ventilated double transparent facades
}

Daniel Urbán, Nicolaas Roozen, Peter Zat’ko, Monika Rychtáriková, Peter Tomašovič, and Christ Glorieux

Citation: Proc. Mtgs. Acoust. 30, 015004 (2017); doi: 10.1121/2.0000538

View online: https://doi.org/10.1121/2.0000538

View Table of Contents: https://asa.scitation.org/toc/pma/30/1

Published by the Acoustical Society of America

\section{ARTICLES YOU MAY BE INTERESTED IN}

Perception of acoustic comfort in large halls covered by transparent structural skins

Proceedings of Meetings on Acoustics 30, 015005 (2017); https://doi.org/10.1121/2.0000540

The effects of the element damping in sound insulation predictions following EN12354

Proceedings of Meetings on Acoustics 30, 015003 (2017); https://doi.org/10.1121/2.0000537

The repeatability and reproducibility of laboratory building acoustic measurements: Numerical study

Proceedings of Meetings on Acoustics 30, 015001 (2017); https://doi.org/10.1121/2.0000530

Human echolocation in different situations and rooms: Threshold values

Proceedings of Meetings on Acoustics 30, 015002 (2017); https://doi.org/10.1121/2.0000536

Psychophysical audiogram of a California sea lion listening for airborne tonal sounds in an acoustic chamber Proceedings of Meetings on Acoustics 30, 010001 (2017); https://doi.org/10.1121/2.0000525

Influence of visual rendering on the acoustic judgements of a theater auralization

Proceedings of Meetings on Acoustics 30, 015008 (2017); https://doi.org/10.1121/2.0000575 


\section{(5) Proceedings of Meetings on Acoustics}

Volume 30

http://acousticalsociety.org/

\section{Acoustics `17 Boston}

173rd Meeting of Acoustical Society of America and 8th Forum Acusticum

Boston, Massachusetts

25-29 June 2017

\section{Architectural Acoustics: Paper 1pAAb3}

\section{Acoustics of naturally ventilated double transparent facades}

\section{Daniel Urbán}

Faculty of Civil Engineering, Department of Building Structures, Slovak University of Technology in Bratislava, Bratislava,SLOVAKIA; ing.daniel.urban@gmail.com

\section{Nicolaas Roozen}

KU Leuven, Department of Physics and Astronomy, Soft Matter and Biophysics, Laboratory of Acoustics,Celestijnenlaan 200D, 3001,Leuven,BELGIUM; bert.roozen@kuleuven.be

\section{Peter Zat'ko}

A\&Z Acoustics s.r.o., Repa ssk'eho 2, 84102,Bratislava, SLOVAKIA; akustika@akustika.sk

Monika Rychtáriková

Faculty of Civil Engineering, Department of Building Structures, STU Bratislava, Radlinsk'eho 11, 81368 , Bratislava, SLOVAKIA; KU Leuven, Faculty of Architecture, Hoogstraat 51, 9000, Gent, BELGIUM;

Monika.Rychtarikova@fys.kuleuven.be

\section{Peter Tomašovič}

Faculty of Civil Engineering, Department of Building Structures, STU Bratislava, Radlinsk'eho 11, 813 68, Bratislava,SLOVAKIA; tomasov@svf.stuba.sk

\section{Christ Glorieux}

KU Leuven, Department of Physics and Astronomy, Soft Matter and Biophysics, Laboratory of Acoustics,Celestijnenlaan 200D,3001,Leuven,BELGIUM; christ.glorieux@kuleuven.be

This publication presents results of research on naturally ventilated Double Transparent Facades (DTF). The influence of the structural design of DTFs on the airborne sound insulation was investigated. For this purpose, 9 DTFs were measured in situ and 9 Double Transparent Façade Elements (DTF) were measured in a laboratory setting. The influence of the cavity thickness, the parallelism of the constitution layers, the amount of absorbing surfaces in the cavity, and the presence ventilation slots were investigated. Based on the performed measurements, a prediction model that allows a fast engineering calculation of the sound insulation of DTF's was developed.

Published by the Acoustical Society of America 


\section{INTRODUCTION}

Double transparent facades (DTF) are used quite often in European countries. Their construction has been refined over many years of research. Developers have sought for new approaches to overcome the disadvantages of single layer lightweight transparent facades. The main priority in building physics research went mainly to aspects of energy efficiency, indoor climate, ventilation and daylight ${ }^{1-5}$. Nowadays progress of DTF performance in terms of thermo-technical aspects concerning energy, aerodynamics, structural requirements, and aerodynamics, is demonstrated by a large number of reports in literature ${ }^{6-9}$. It should be noted that due to economic reasons, DTFs are mainly used in administrative buildings.

The presented work deals with naturally ventilated Double Transparent Facades (DTF). From a building acoustics point of view, DTFs allow for natural ventilation in buildings while keeping the indoor sound pressure levels caused by exterior noise to reasonable levels ${ }^{10-14}$. On the other hand, by increasing the façade sound insulation, the background noise resulting from outdoor sound sources is attenuated. Previous research shows that, if the background noise in a DTF cavity is lower than $62 \mathrm{~dB}$, it is possible to understand the speech from a neighboring room. The Speech Transmission Index (STI) is most sensitive to the vertical cross section area of cavity. When decreasing the overall width of the DTF, also the STI and G values decrease. The differences between different locations in the room have been found to be small. For non-parallel and thin cavities, the expression for the sound insulation between two spaces proposed in EN ISO 12354-1 gives different results than simulations ${ }^{15}$.

In the following, we discuss the influence of the structural design of DTFs on the airborne sound insulation. For this purpose, 9 DTFs were measured in situ and 9 Double Transparent Façade Elements were measured in a laboratory setting. The influence of the cavity thickness, the parallelism of the constitution layers, the amount of absorbing surfaces in the cavity, and the effect of ventilation slots were investigated. Based on the performed measurements, a prediction model that allows a fast engineering calculation of the sound insulation of DTF's is validated ${ }^{16}$.

\section{CASE STUDY EXPLANATION}

\section{A. IN SITU MEASUREMENTS}

Nine naturally ventilated double skin facades (DSF) were measured. The measurements were carried out in accordance to standard EN ISO 16283-1 ${ }^{17}$. One additional microphone position was chosen inside of the DTF cavity to get partial information about sound pressure level difference inside of the façade. Based on the measured data a combination of mass law behavior, standing wave induced resonances in the cavity and air coupling around and above the coincidence frequency were analysed. The influence of the kind of DTF ventilation on the sound insulation was investigated. In some cases a disadvantage of lightweight blinding systems and shields usage in the cavity became clear. The air flow in the cavity could be high, and some of the lightweight parts induced the additional noise in the cavities.

\section{B. LABORATORY MEASUREMENTS}

For 9 different glass window DTF-like arrangements, laboratory measurements were performed in accordance with standard ISO 10140-4 ${ }^{18}$. Also the sound pressure level in the DTF was analysed. The influence of the cavity thickness, the parallelism of the two glass panels, the absorptivity of the cavity, and the effect of ventilation slots were investigated. 


\section{ENGINEERING PREDICTION MODEL DESCRIPTION}

One of the goals of this work was to verify an engineering prediction model approach for the calculation of sound insulation spectra of naturally ventilated DTF ${ }^{16}$. The model was developed based on the responses of the individual parts of the facade. The individual sound insulation of each panel was determined by means of standard approaches in advance ${ }^{19}$. The contribution to the sound transmission of ventilation slots was modeled as proposed in ${ }^{20}$. The tested engineering prediction model divides the sound insulation spectrum into three frequency ranges.

The cavity eigenmode frequency range: In the part of the spectrum below the cavity eigenmode frequency, the sound insulation can be approximated as a sum of the individual insulations of the two panels, decremented by $4 \mathrm{~dB}$.

The frequency range with sound insulation behavior dominated by the transmission of sound via ventilation slots: In the frequency range between the cavity eigenmode frequency and the coincidence frequency of the exterior panel, a model was developed in ${ }^{16,21}$. For ventilation by open slots, the sound insulation of the exterior window is to an important extent neutralized, reducing the overall sound insulation by $6 \mathrm{~dB}$ /octave. For ventilation by a mesh or a grill, the overall sound insulation is reduced by $9 \mathrm{~dB} /$ octave.

The frequency range above the coincidence frequency: In this frequency range, the sound insulation was calculated as the sound insulation of the dominant layer increased by $6 \mathrm{~dB}$.

\section{CONCLUSION}

Based on in situ and laboratory measurements, it was found that, the sound insulation of DTF is affected by type of ventilation slots and acoustic standing waves in the cavity. The usual improvement of sound insulation by ventilated layer (external layer) is in range of $\Delta R_{w}=5$ to $9 \mathrm{~dB}$. In the absence of ventilation slots, the insulation increased up to almost $20 \mathrm{~dB}$ for window size elements. The effect of the increasing the cavity thickness by $16 \%$ and shape non-parallelism of $50 \mathrm{~mm}$ on the sound insulation spectrum was found to be negligible. On the other hand., placing absorbing material along the sides of the cavity increased $R_{w}$ about 7-8 dB. This approach was effective both for open and closed cavity. Placement of absorptive material increased the slope of the sound insulation curve slope by about $+4 \mathrm{~dB} /$ octave below the coincidence frequency. The engineering prediction model gives roughly good results in the middle and high frequency range. Single number rating sound insulation prediction values were found to be within $1 \mathrm{~dB}$ from experimental values. The low frequency insulation still remains difficult to predict.

\section{ACKNOWLEDGMENTS}

This research was supported by H2020-MSCA-RISE-2015 No. 690970 „papabuild”, VEGA 1/0067/16,APVV-16-0126, University science park STU Bratislava - 2nd phase ITMS 313021D243 and COST TU1303 Novel structural skins: Improving sustainability and efficiency through new structural textile materials and designs.

\section{REFERENCES}

${ }^{1}$ E. Gratia, A. De Herde, Natural ventilation in a double-skin facade, Energ Buildings 36(2) (2004) 137-146.

${ }^{2}$ E. Gratia, A. De Herde, Guidelines for improving natural daytime ventilation in an office building with a double-skin facade, Sol Energy 81(4) (2007) 435-448.

${ }^{3}$ C. Balocco, M. Colombari, Thermal behaviour of interactive mechanically ventilated double glazed facade: Non-dimensional analysis, Energ Buildings 38(1) (2006) 1-7. 
${ }^{4}$ T. Herzog, Krippner, R., Lang, W., Facade construction manual, 1st ed., Birkhauser-Publishers for Architecture, Basel ; Boston, 2004.

${ }^{5}$ M. Torres, P. Alavedra, A. Guzman, E. Cuerva, C. Planas, R. Clemente, V. Escalona, Double Skin Facades - Cavity and exterior openings dimensions for saving energy on Mediterranean climate, Building Simulation 2007, Vols 1-3, Proceedings (2007) 198-205.

${ }^{6}$ M. Ciampi, F. Leccese, G. Tuoni, Ventilated facades energy performance in summer cooling of buildings, Sol Energy 75(6) (2003) 491-502.

${ }^{7}$ E. Gratia, A. De Herde, Natural cooling strategies efficiency in an office building with a double-skin facade, Energ Buildings 36(11) (2004) 1139-1152.

${ }^{8}$ A. Zollner, E.R.F. Winter, R. Viskanta, Experimental studies of combined heat transfer in turbulent mixed convection fluid flows in double-skin-facades, Int J Heat Mass Tran 45(22) (2002) 4401-4408.

${ }^{9}$ E. Gratia, A. De Herde, Greenhouse effect in double-skin facade, Energ Buildings 39(2) (2007) 199211.

${ }^{10}$ Y.H.K. Pyoung Jik Leea, Jin Yong Jeona, Kyoo Dong Song, Effects of apartment building fac-ade and balcony design on the reduction of exterior noise, Build Environ 42 (2007) 3517-3528.

${ }^{11}$ A.A. Shinichi Sakamoto, Numerical and experimental study on noise shielding effect of eaves/ louvers attached on building facade, Build Environ 94 (2015) 773-784.

${ }^{12}$ S.H. Chi-Ming Lai, Solar façades: A review, Build Environ 91 (2015) 152-165.

${ }^{13}$ J.M. Blanco, Arriaga, P., Rojí, E., Cuadrado, J., Investigating the thermal behavior of double-skin perforated sheet façades: Part A: Model characterization and validation procedure, Build Environ 82 (2014) 50-62.

${ }^{14}$ V. Huckemann, Kuchen, E., Leao, M., Leao, E. F.T.B. , Empirical thermal comfort evaluation of single and double skin façades, Build Environ 45 (2010) 976-982.

${ }^{15}$ D. Urbán, Tomašovič, P., Rychtáriková, M.,Roozen, N.B., Glorieux, CH. , Sound propagation within a double skin facade and its influence on the speech privacy in offices. , in: EAA (Ed.) Euronoise 2015, Maastricht, The Netherlands. , 2015, pp. 2543- 2548.

${ }^{16}$ D. Urbán, Roozen, N. B., Zat'ko, P., Rychtáriková, M., Tomašovič, P., Glorieux, C. , Assessment of sound insulation of naturally ventilated double skin facades., Building and Environment 110 (2016) 148-160.

${ }^{17}$ EN ISO 16283-1:2014; Acoustics - Field measurement of sound insulation in buildings and of building elements - Part 1: Airborne sound insulation, 2014.

${ }^{18}$ Acoustics.Laboratory measurement of sound insulation of building elements., Part 4:Measurement procedures and requirements (ISO 10140-4:2010), 2010.

${ }^{19}$ Č. J., Stavební fyzika 10- akustika stavebních konstrukcí., ČVUT, Praha, 1997.

${ }^{20}$ J.H. Rindel, Transmission of traffic noise trough windows., Lyngby, Technical University of Denmark, 1975.

${ }^{21}$ F. Fahy, Sound and Strucutral Vibration, Academic press, Institute of Sound and Vibration Research The University Southampton, England, 1985. 